\title{
Bioaccumulation potential of In vitro regenerated plants of Ceratophyllum demersum against Chromium - A lab study
}

Muhammad Aasim¹ ${ }^{*}$, Senar Aydın², Mehmet Karataş ${ }^{3}$, Mehmet Emin Aydın4, Canan Soğukpınar4, Canan Sevinc ${ }^{3}$

${ }^{1}$ Department of Plant Protection, Faculty of Agricultural Sciences and Technologies, Sivas University of Science and Technology, 58140, Sivas, Turkey

${ }^{2}$ Department of Environmental Engineering, Faculty of Engineering and Architecture, Necmettin Erbakan University, Konya, Turkey ${ }^{3}$ Department of Biotechnology, Faculty of Science, Necmettin Erbakan University, Konya, Turkey

${ }^{4}$ Department of Civil Engineering, Faculty of Engineering and Architecture, Necmettin Erbakan University, Konya, Turkey

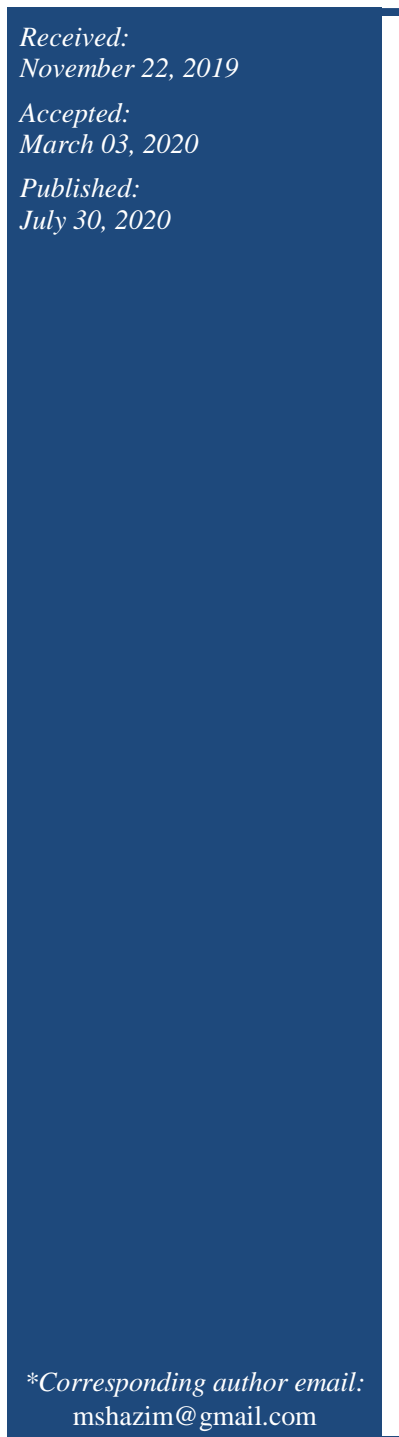

\begin{abstract}
Phytoremediation of contaminated environment using hyperaccumulator plants is considered as ecofriendly and cost-effective technique. Aquatic plants like Ceratophyllum demersum (Coontail) is used for the phytoremediation of aquatic environment contaminated by heavy metals. In this study, in vitro regenerated plants of C. demersum were exposed to different concentrations of Chromium $(\mathrm{Cr})(0,3,6,9,12$ and $\left.15 \mathrm{mg} \mathrm{L}^{-1}\right)$ for different exposure time (1, 3 and 5 days) in order to investigate the phytoremediation potential. The plants contained in $\mathrm{Cr}$ containing liquid medium were cultured in growth room having $16 \mathrm{hr}$ light photoperiod aided by white Light Emitting Diodes (LEDs) and temperature of $24 \pm 1^{\circ} \mathrm{C}$. The plant samples were taken out from liquid medium after 1, 3 and 5 days for taking data regarding fresh weight, dry weight, $\mathrm{Cr}$ uptake by plants and bioconcentration factor (BCF). The clear relationship between $\mathrm{Cr}$ concentration and exposure time on phytoremediation was revealed. Both fresh and dry weight of plants was recorded higher at variable $\mathrm{Cr}$ concentration compared to control plants. The exposure time of 3 days to $\mathrm{Cr}$ caused the maximum $\mathrm{Cr}$ uptake, followed by further uptake of $\mathrm{Cr}$ at relatively slow rate after 5 days. The highest $\mathrm{Cr}$ uptake and BCF was achieved from medium provided with $12 \mathrm{mg} \mathrm{L}^{-1}$ and $3 \mathrm{mg} \mathrm{L}^{-1}$ of $\mathrm{Cr}$ respectively. Comparison of exposure time exposure time $\times \mathrm{Cr}$ concentration revealed the highest $\mathrm{Cr}$ uptake $\left(9145 \mathrm{mg} \mathrm{kg}^{-1}\right.$ ) and $\mathrm{BCF}$ value (2076.5) from the combination of $12 \mathrm{mg} \mathrm{L}^{-1} \times 5 \mathrm{~d}$ and $3 \mathrm{mg} \mathrm{L}^{-1} \times 5 \mathrm{~d}$ respectively. The results revealed that in vitro regenerated plants of $C$. demersum can be used for phytoremediation of $\mathrm{Cr}$ and possibly use against other heavy metals.
\end{abstract}

Keywords: Bioconcentration factor, Chromium, C. demersum, Phytoremediation, Water

\section{How to cite this:}

Aasim M, Aydın S, Karataş M, Aydın ME, Soğukpınar C and Sevinc C, 2020. Bioaccumulation potential of In vitro regenerated plants of Ceratophyllum demersum against Chromium - A lab study. Asian J. Agric. Biol. 8(3): 233-239. DOI: https://doi.org/10.35495/ajab.2019.11.516

This is an Open Access article distributed under the terms of the Creative Commons Attribution 3.0 License. (https://creativecommons.org/licenses/by/3.0), which permits unrestricted use, distribution, and reproduction in any medium, provided the original work is properly cited. 


\section{Introduction}

Heavy industrialization in the $20^{\text {th }}$ century in both developed and underdeveloped countries lead to accumulation of heavy metal to the environment $(\mathrm{Fu}$ and Wang, 2011) and water (Sadik et al., 2015). The issue of heavy metal pollutions is now considered as one of the major threat to humans (Zheng et al., 2016) and other living organisms due to its cycle of transfer from non-living to living organisms (Akpor and Muchie, 2011). The water bodies all over the world are more prone to heavy metal contaminants due to release of heavy metals to aquatic environment especially in under developed countries where, violation of rules and lack of resources are main hinders to overcome this issue. To overcome this issue of heavy metal contamination in the water bodies, different methods like physical, chemical, and biological processes are used either singly or in combinations (Ali et al., 2017). Phytoremediation is one of the popular, ecofriendly and cost-effective system used for cleaning water and soil (Ali et al., 2013; Cao et al., 2017). This system has been reported for bioremediation of water bodies or aquatic environment (Harguinteguy et al., 2016; Xu et al., 2019) using submerged aquatic plants (Thiébaut, 2012) like $C$. demersum L. (Chen et al., 2015). The coontail is rootless, submerged and perennial aquatic macrophyte which prefers to live in shallow water with low light intensity (Polechonska et al., 2018). Its rapid propagation and high biomass in water bodies make it an important macrophyte which absorbs elements easily from its surrounding (Wang et al., 2014; Polechonska et al., 2018). However, the main issue related with this system is the availability of plants which must be free of heavy metals (Dogan et al., 2018). Plant tissue culture technique offers a solution of plant availability propagated under controlled conditions and without adhering to external conditions (George et al., 2008). Keeping in view, this study was designed to check the phytoremediation potential of in vitro propagated $C$. demersum plants subjected to variable concentrations of Chromium $(\mathrm{Cr})$ under lab conditions. This study will open the window for using such type of plants under natural ecological environments.

\section{Material and Methods}

\section{Experimental labs}

The experiments about in vitro propagation and phytoremediation studies were carried out at Plant
Biotechnology Laboratory, Necmettin Erbakan University, Department of Biotechnology. Whereas, work related to $\mathrm{Cr}$ analysis was performed at Environmental Engineering Laboratory of Necmettin Erbakan University, Konya, Turkey.

\section{In vitro propagation of plant material}

For the continuous availability of plant material, nodal segment explants were excised from in vitro stock material available at Plant Biotechnology Laboratory. Explants were isolated from top part of the in vitro stock material and transferred to liquid (Karataş et al., 2014) Murashige and Skoog (MS) medium (Murashige and Skoog, 1962) containing $1.0 \mathrm{mg} \mathrm{L}^{-1}$ 6-Benzylaminopurine (BAP). The MS medium was also enriched with $3.0 \%$ sucrose, $0.44 \%$ MS and adjusted to 5.6-5.8 $\mathrm{pH}$ prior to autoclave. The explants were cultured under white LEDs (1500 LUX) for $16 \mathrm{~h}$ light photoperiod in growth room at $23 \pm 1{ }^{\circ} \mathrm{C}$.

\section{Phytoremediation studies}

All reagents used in phytoremediation study were of analytical grade (Merck®, Germany). $\mathrm{CrCl}_{2}$ (Merck) with mol. wt. of 122.9 was used as salt for phytoremediation studies. The stock solution was prepared at the rate of $50 \mathrm{mg} \mathrm{L}^{-1}$ and stored at $4{ }^{\circ} \mathrm{C}$. $\mathrm{Cr}$ were used at the rate of 3, 6, 9, 12 and $15 \mathrm{mg} \mathrm{L}^{-1}$ along with control containing $0 \mathrm{mg} \mathrm{L^{-1 }} \mathrm{CrCl}_{2}$. Plastic magenta $\mathrm{GA}^{7}$ boxes $(100 \times 100 \times 80 \mathrm{~mm})$ available as sterilized were used for phytoremediation studies. Each $\mathrm{Cr}$ concentration was mixed in $400 \mathrm{~mL}$ solution containing distilled water and later used for culture of plants for phytoremediation. The $\mathrm{pH}$ of the water samples were 7.0 at the time of use of $\mathrm{Cr}$. In vitro regenerated plants of $5-7 \mathrm{~cm}$ were used for phytoremediation studies $(7.5 \mathrm{~g} / \mathrm{L})$ and exposed for three different time intervals of 1,3 and 5 days under growth conditions of $24{ }^{\circ} \mathrm{C}$ and $16 \mathrm{~h}$ light photoperiod using white LEDs.

\section{Plant sampling and analysis}

After phytoremediation for three different days (1, 3 and 5 days), samples were taken out from phytoremediation medium and immediately weighed for fresh wt. The samples were dried on Whatman paper 42, oven dried at $70 \mathrm{oC}$ using oven (Memmert) for 4 days, followed by weighing to measure dry wt. Thereafter, plant samples were mixed with $10 \mathrm{~mL}$ $65 \% \mathrm{HNO}_{3}$ followed by digestion in microwave (CEM, MarsXpress, USA). The material was sieved using Whatman filter papers no 42 and brought the 
volume up to $25 \mathrm{~mL}$ by adding ultra-distilled water, followed by analysis of $\mathrm{Cr}$ by using Atomic Absorption Spectrophotometer (AAS) - Perkin Elmer-800 equipped with flame and graphite furnace. The calibration standard was prepared using $1000 \mathrm{mg}$ $\mathrm{L}^{-1}$ stock solution for Cr. Reagent blanks' concentrations were below the detection limit for the $\mathrm{Cr} .10 \% \mathrm{HNO}_{3}$ were applied for glassware and plastic ware followed by using deionized water for washing. The analysis of each sample was repeated thrice in each replicate for quality assurance. The analysis of mid-concentration of metal was performed after every ten samples. Detection limit of AAS was determined as $0.188 \mu \mathrm{g} / \mathrm{L}$ for $\mathrm{Cr}$.

Heavy metal $(\mathrm{Cr})$ contents in the plants were expressed as $\mathrm{mg} \mathrm{kg}^{-1}$ dry weight (dw) using appropriate conversion formula. Bioconcentration Factor (BCF) of C. demersum plants subjected to different concentrations was formulated by using formula (Zayed et al., 1998; Dogan et al., 2018).

$\mathrm{BCF}=$ Trace element concentration in plant tissue $\left(\mathrm{mg} \mathrm{kg}^{-1}\right) /$ First concentration of the element added to water $\left(\mathrm{mg} \mathrm{L}^{-1}\right)$.

\section{Statistical analysis}

Data about shoot fresh and dry wt, Cr concentration in plants and BCF were tabulated and subjected to statistical analysis for One Way ANOVA (analysis of variance) with the help of SPSS 21 for Windows (SPSS Inc. Chicago, IL, USA) program. Duncan's Multiple Range Test (DMRT) at $p<0.01$ level of significance was used for comparing means. The data given in percentages (\%) were transformed arcsine $(\sqrt{X})$ form (Snedecor and Cochran, 1997) before subjecting them to ANOVA and DMRT.

\section{Results and Discussion}

The application of hyperaccumulator aquatic plants are highly significant for the cleaning of water bodies contaminated with wide arrays of pollutants like heavy metals. There are number of aquatic plants which are recommended for phytoremediation studies like $C$. demersum (Chen et al., 2015; Dogan et al. 2018), Lemna minor and Lemna gibba (Sasmaz et al., 2016). Among these, C. demersum is highly effective aquatic plants used for phytoremediation against different pollutants found in water bodies (Abdallah 2012; Vahdatiraad and Khara 2012; Hassan and AlKhalidi 2018).
The phytoremediation potential of $C$. demersum plants subjected to different concentrations of $\mathrm{Cr}$ exhibited significant impact on plant growth during phytoremediation phase (Terzi and Yildiz 2011). The exposure time significantly $(p<0.01)$ affected the fresh wt, dry wt, Cr uptake by plant and BCF in similar fashion. All parameters increased with increase in exposure time (Table 1) and recorded as 2.99-5.14 g (fresh wt), 57-92 mg (dry wt), 2586.92-6509.67 mg $\mathrm{kg}^{-1}$ (Cr uptake by plants) and BCF value of 406.58927.50 (Table 1). Previously, elevated $\mathrm{Cd}$ and $\mathrm{Pb}$ uptake by $C$. demersum with increase of exposure time has been reported respectively by Al- Ubaidy and Rasheed (2015) and Chen et al., (2015). Whereas, Dogan et al., (2018), linked the decreased plant growth and chlorophyll contents of $C$. demersum plants with exposure time. Similarly, the impact of exposure time on metal accumulation and plant growth have been reported by other researchers using different aquatic macrophytes (Singh et al. 2010; Sasmaz et al. 2016).

Table-1: Impact of exposure time on plant growth and phytoremediation potential of $C$. demersum plants

\begin{tabular}{|c|c|c|c|c|}
\hline Day & $\begin{array}{c}\text { Fresh Wt } \\
(\mathbf{g})\end{array}$ & $\begin{array}{c}\text { Dry Wt } \\
(\mathbf{m g})\end{array}$ & $\begin{array}{c}\text { Cr Uptake } \\
\left(\mathrm{mg} \mathrm{kg}^{-1}\right)\end{array}$ & BCF \\
\hline 1 & $2.99 \mathrm{a}$ & $57 \mathrm{~b}$ & $2586.92 \mathrm{c}$ & $406.58 \mathrm{c}$ \\
\hline 3 & $4.91 \pm 0.51 \mathrm{~b}$ & $90 \mathrm{a}$ & $4916.08 \mathrm{~b}$ & $724.58 \mathrm{~b}$ \\
\hline 5 & $5.14 \pm 0.59 \mathrm{a}$ & $92 \mathrm{a}$ & $6509.67 \mathrm{a}$ & $927.50 \mathrm{a}$ \\
\hline
\end{tabular}

Means followed by different small letters within columns are significantly different using DMRT test at $p<0.01$

Application of $\mathrm{Cr}$ concentration exerted statistical effect $(p<0.01)$ on all parameters tested. Fresh wt and dry wt in response to $\mathrm{Cr}$ concentration ranged 4.06$4.64 \mathrm{~g}$ and 76-84 $\mathrm{mg}$ respectively (Table 2). Both highest fresh wt and dry wt was recorded for medium supplemented with $9 \mathrm{mg} \mathrm{L}^{-1} \mathrm{Cr}$. Earlier, Doğan et al., (2018) reported toxic effects of Cr on plant growth and pigmentation of $C$. demersum exposed to different concentrations. The $\mathrm{Cr}$ uptake by plants was statistically similar up to $9 \mathrm{mg} \mathrm{L}^{-1}$ of Cr. However, the maximum $\mathrm{Cr}$ uptake by plants was attributed to medium having $12 \mathrm{mg} \mathrm{L}^{-1} \mathrm{Cr}$ but further increase of $\mathrm{Cr}$ led to decreased uptake by plants. The BCF values decreased significantly with increased $\mathrm{Cr}$ concentration in the medium and ranged 373.671679.83 (Table 2). Decreased BCF value with elevated concentration of $\mathrm{Cr}$ (Doğan et al., 2018) or $\mathrm{Cd}$ 
(Bunluesin et al., 2004; Das et al., 2016; Dogan et al., 2018) have also been reported.

Table-2: Impact of $\mathrm{Cr}$ concentration on plant growth and phytoremediation potential of $C$. demersum plants

\begin{tabular}{|c|c|c|c|c|}
\hline $\begin{array}{c}\text { Conc } \\
\left(\mathrm{mg} \mathrm{L}^{-1}\right)\end{array}$ & $\begin{array}{c}\text { Fresh Wt } \\
(\mathbf{g})\end{array}$ & $\begin{array}{c}\text { Dry wt } \\
(\mathbf{m g})\end{array}$ & $\begin{array}{c}\text { Cr Uptake } \\
\left(\mathrm{mg} \mathrm{kg}^{-1}\right)\end{array}$ & BCF \\
\hline 0 & $4.18 \mathrm{bc}$ & $76 \mathrm{c}$ & $0.00 \mathrm{c}$ & 0.00 \\
\hline 3 & 4.06 & $77 \mathrm{c}$ & $5039.67 \mathrm{~b}$ & $1679.83 \mathrm{a}$ \\
\hline 6 & $4.35 \mathrm{abc}$ & $81 \mathrm{ab}$ & $5667.67 \mathrm{~b}$ & $944.83 \mathrm{~b}$ \\
\hline 9 & $4.64 \mathrm{a}$ & $84 \mathrm{a}$ & $5145.33 \mathrm{~b}$ & $571.50 \mathrm{c}$ \\
\hline 12 & $4.45 \mathrm{ab}$ & $80 \mathrm{bc}$ & $6569.83 \mathrm{a}$ & $547.50 \mathrm{c}$ \\
\hline 15 & $4.39 \mathrm{abc}$ & $81 \mathrm{ab}$ & $5602.83 \mathrm{~b}$ & $373.67 \mathrm{~d}$ \\
\hline
\end{tabular}

Means followed by different small letters within columns are significantly different using DMRT test at $p<0.01$

The exposure of plants to different $\mathrm{Cr}$ concentrations and time interval (exposure time $\times \mathrm{Cr}$ conc.) significantly affected the plant growth which in turn resulted in variable response on fresh and dry wt of phytoremediated plants. Both fresh and dry wt parameters reflect the toxicity level of phytoremediated plants. Different researchers highlighted the variable response of plants exposed to different heavy metals at variable concentrations (Cedergreen, 2008; Duman and Koca, 2014). There was slight change in fresh wt after 1 day but after 3 days, plants showed significant growth and gained significant fresh wt in response to different concentrations of $\mathrm{Cr}$. Maximum fresh wt was achieved from medium supplemented with $9 \mathrm{mg} \mathrm{L}^{-1}$ Cr followed by $12 \mathrm{mg} \mathrm{L}^{-1} \mathrm{Cr}$ after 3 days (Table 3). The further increase of $\mathrm{Cr}$ concentration was highly detrimental and resulted in reduced fresh wt.

Comparing exposure time, clear change in fresh wt. was recorded between one and three days of exposure. Whereas, slight change of fresh wt. between three and five days exposure time was recorded (Table 3 ). These results suggested that plants took time for adaptation in the $\mathrm{Cr}$ medium within $24 \mathrm{hr}$ (1 day) followed by enhanced growth in the medium up to 3 days. Thereafter, plants growth remained slow due to exposing further to $\mathrm{Cr}$ concentration for 2 more days. The results further suggest that plants can survive and continue to grow at higher concentration of $\mathrm{Cr}$ up to 3 days but further exposure time may lead to slow plant growth. Negative impact of $\mathrm{Cr}$ on plant biomass of $C$. demersum has been reported by Doğan et al., (2018). Similarly, negative impact of $\mathrm{Cd}$ or $\mathrm{Pb}$ concentration and exposure time on fresh wt of $C$. demersum has also reported (Dogan et al., 2018). Similar types of results were also tested by Mishra et al., (2006) and Chen et al., (2015), when exposed C. demersum plants to $\mathrm{Pb}$ for 1-7 days.

Table-3: Impact of exposure time $\times \mathrm{Cr}$ concentration on fresh wt (g) and dry wt (mg) of phytoremediated $C$. demersum plants

\begin{tabular}{|c|c|c|c|c|c|c|}
\hline \multirow{2}{*}{$\begin{array}{c}\mathbf{C r} \\
\left(\mathrm{mg} \mathrm{L}^{-1}\right)\end{array}$} & \multicolumn{3}{|c|}{ Fresh Wt (g) } & \multicolumn{2}{c|}{ Dry Wt (mg) } \\
\hline $\mathbf{0}$ & $2.848 \mathrm{f}$ & $4.574 \mathrm{de}$ & $5.134 \mathrm{bcd}$ & $52 \mathrm{~g}$ & $94 \mathrm{bc}$ & $82 \mathrm{e}$ \\
\hline $\mathbf{3}$ & $2.827 \mathrm{f}$ & $4.765 \mathrm{cde}$ & $4.593 \mathrm{de}$ & $55 \mathrm{fg}$ & $88 \mathrm{cde}$ & $87 \mathrm{cde}$ \\
\hline $\mathbf{6}$ & $3.376 \mathrm{f}$ & $4.813 \mathrm{cde}$ & $4.862 \mathrm{cde}$ & $60 \mathrm{f}$ & $94 \mathrm{bc}$ & $89 \mathrm{cde}$ \\
\hline $\mathbf{9}$ & $3.021 \mathrm{f}$ & $5.557 \mathrm{ab}$ & $5.343 \mathrm{abc}$ & $59 \mathrm{f}$ & $93 \mathrm{bc}$ & $99 \mathrm{ab}$ \\
\hline $\mathbf{1 2}$ & $2.899 \mathrm{f}$ & $5.328 \mathrm{abc}$ & $5.120 \mathrm{bcd}$ & $60 \mathrm{f}$ & $89 \mathrm{cde}$ & $90 \mathrm{~cd}$ \\
\hline $\mathbf{1 5}$ & $3.001 \mathrm{f}$ & $4.398 \mathrm{e}$ & $5.762 \mathrm{a}$ & $57 \mathrm{fg}$ & $82 \mathrm{de}$ & $104 \mathrm{a}$ \\
\hline
\end{tabular}

Means followed by different small letters within columns are significantly different using DMRT test at $p<0.01$

Results exhibited the clear impact of exposure time and $\mathrm{Cr}$ concentration on dry wt. of phytoremediated plants. Dry wt ranged 51-60 mg with highest dry wt. from $12 \mathrm{mg} \mathrm{L}^{-1} \mathrm{Cr}$ after 1 day. After 3 days, fresh wt. increased significantly and ranged 79-94 mg (Table 3) with minimum dry wt. was achieved from samples containing $15 \mathrm{mg} \mathrm{L}^{-1} \mathrm{Cr}$. After 5 days, variable dry wt. was observed and ranged 82-104 $\mathrm{mg}$ with highest from $15 \mathrm{mg} \mathrm{L}^{-1} \mathrm{Cr}$ (Table 3). The dry wt. of phytoremediated plants was in general higher than control plants. These results do not support the findings of Doğan et al (2018), who reported decreased dry wt. compared to control plants. Dogan et al., (2018) also reported decreased dry wt. with increased $\mathrm{Cd}$ or $\mathrm{Pb}$ concentration compared to control group of in vitro $C$. demersum plants. These results suggested that dry wt of phytoremediated plants is not related to their respective fresh wt. and can increase or decreased with with exposure time, heavy metal type or concentration.

Ceratophyllum demersum is well known plant for heavy metals phytoremediation in the water bodies. The analysis of phytoremediated plants revealed the clear relationship between exposure time and $\mathrm{Cr}$ concentration on the uptake by plants. The uptake of $\mathrm{Cr}$ by plants was recorded between 2766 to $3393 \mathrm{mg}$ $\mathrm{kg}^{-1}$ after $1^{\text {st }}$ day, 5103 to $7536 \mathrm{mg} \mathrm{kg}^{-1}$ after 3 days and $6229-9145 \mathrm{mg} \mathrm{kg}^{-1}$ after 5 days of phytoremediation. The highest uptake was recorded from medium containing $12 \mathrm{mg} \mathrm{L}^{-1} \mathrm{Cr}$ after 3 and 5 days (Table 2). There was no detection of $\mathrm{Cr}$ in the control plants. These results confirmed the previous findings of 
Doğan et al., (2018), who also observed increased Cr uptake with increase in $\mathrm{Cr}$ concentration. Earlier, Duman et al. (2010) also reported accumulation of $\mathrm{Cr}$ by $C$. demersum plants up to 6 days, when used at the rate of 1,5 , and $10 \mathrm{mM}$.

Table-4: Impact of exposure time $\times \mathrm{Cr}$ concentration on uptake of $\mathrm{Cr}$ conc $\left(\mathrm{mg} \mathrm{kg}^{-1}\right)$ by phytoremediated $C$. demersum plants

\begin{tabular}{|c|c|c|c|}
\hline $\mathbf{C r}\left(\mathrm{m} \mathrm{L} \mathrm{L}^{-1}\right)$ & $\mathbf{1 ~ d}$ & $\mathbf{3 d}$ & $\mathbf{5 d}$ \\
\hline $\mathbf{0}$ & $0 \mathrm{f}$ & $0 \mathrm{f}$ & $0 \mathrm{f}$ \\
\hline $\mathbf{3}$ & $3302 \mathrm{e}$ & $5588 \mathrm{~d}$ & $6229 \mathrm{~cd}$ \\
\hline $\mathbf{6}$ & $3393 \mathrm{e}$ & $5382 \mathrm{~d}$ & $8227 \mathrm{ab}$ \\
\hline $\mathbf{9}$ & $3033 \mathrm{e}$ & $5103 \mathrm{~d}$ & $7301 \mathrm{bc}$ \\
\hline $\mathbf{1 2}$ & $3029 \mathrm{e}$ & $7536 \mathrm{~b}$ & $9145 \mathrm{a}$ \\
\hline $\mathbf{1 5}$ & $2766 \mathrm{e}$ & $5887 \mathrm{~d}$ & $8156 \mathrm{ab}$ \\
\hline
\end{tabular}

Means followed by different small letters within columns are significantly different using DMRT test at $p<0.01$

Table-5: Impact of exposure time $\times \mathrm{Cr}$ concentration on bioaccumulation factor $(\mathrm{BCF})$ of phytoremediated $C$. demersum plants

\begin{tabular}{|c|c|c|c|}
\hline $\mathbf{C r}\left(\mathrm{mg} \mathrm{L}^{-1}\right)$ & $\mathbf{1 ~ d}$ & $\mathbf{3 ~ d}$ & $\mathbf{5 ~ d}$ \\
\hline $\mathbf{0}$ & $.00 \mathrm{i}$ & $.00 \mathrm{i}$ & $.00 \mathrm{i}$ \\
\hline $\mathbf{3}$ & $1100.50 \mathrm{c}$ & $1862.50 \mathrm{a}$ & $2076.50 \mathrm{a}$ \\
\hline $\mathbf{6}$ & $565.50 \mathrm{efg}$ & $897.50 \mathrm{~cd}$ & $1371.50 \mathrm{~b}$ \\
\hline $\mathbf{9}$ & $336.50 \mathrm{gh}$ & $567.00 \mathrm{efg}$ & $811.00 \mathrm{de}$ \\
\hline $\mathbf{1 2}$ & $252.50 \mathrm{hi}$ & $628.00 \mathrm{ef}$ & $762.00 \mathrm{de}$ \\
\hline $\mathbf{1 5}$ & $184.50 \mathrm{hi}$ & $392.50 \mathrm{fgh}$ & $544.00 \mathrm{efg}$ \\
\hline
\end{tabular}

Means followed by different small letters within columns are significantly different using DMRT test at $p<0.01$

BCF exhibits the metal uptake or accumulation capacity of the phytoremediated plant (Kara and Zeytunluoglu, 2007) from ecological site either soil or aquatic environment (Zayed et al., 1998). The results revealed the significant impact of $\mathrm{Cr}$ concentration and exposure time on BCF. The highest BCF after 1 day was 1100.50 from medium supplemented with $3.0 \mathrm{mg}$ $\mathrm{L}^{-1} \mathrm{Cr}$. The same pattern was also followed after 3 days (1862.50) and 5 days (2076.50) (Table 3) and confirmed the previous findings of Doğan et al., (2018). It was also noted that BCF concentration showed decreased pattern with increase of $\mathrm{Cr}$ concentration in the medium irrespective of exposure time. Decreased $\mathrm{BCF}$ value with increase of $\mathrm{Cd}$ (Bunluesin et al., 2004) or $\mathrm{Pb}$ (Abdallah, 2012) concentration has been reported for $C$. demersum used for phytoremediation.

\section{Conclusion}

The study reflects the possible phytoremediation potential of in vitro regenerated $C$. demersum plants against $\mathrm{Cr}$ under lab conditions. The results suggest that $\mathrm{Cr}$ in the medium significantly affected the fresh wt. and dry wt. of phytoremediated plants compared to control plants. The uptake of $\mathrm{Cr}$ from the medium by in vitro regenerated plants was fast and highest after 3 days. Although, plants continuously uptake $\mathrm{Cr}$ from the medium, the speed was relatively slow. The BCF was highest to lowest with elevated $\mathrm{Cr}$ concentration. These results clearly emphasize the potential of in vitro regenerated plants for phytoremediation studies for $\mathrm{Cr}$ under lab conditions and there is need to carry experiments for phytoremediation studies under natural ecological environments or subjecting the plants to polluted water under lab conditions.

\section{Acknowledgment}

This study was conducted under research project No. 171715001 funded by Scientific Research Council (BAP) of Necmettin Erbakan University, Konya, Turkey.

Disclaimer: None.

Conflict of Interest: None.

Source of Funding: This study was funded by Scientific Research Council (BAP) of Necmettin Erbakan University, Konya, Turkey.

\section{References}

Abdallah MAM, 2012. Phytoremediation of heavy metals from aqueous solutions by two aquatic macrophytes, Ceratophyllum demersum and Lemna gibba L. Environ. Technol. 33: 16091614.

Akpor OB and Muchie M, 2011. Environmental and public health implications of wastewater quality. Afr. J. Biotechnol. 10: 2379-2387.

Ali A, Guo D, Mahar A, Wang P, Ma F, Shen F, Li $\mathrm{R}$ and Zhang Z, 2017. Phytoextraction of toxic trace elements by Sorghum bicolor inoculated with Streptomyces pactum (Act12) in contaminated soils. Ecotoxicol. Environ. Saf. 139: 202-220 
Ali H, Khan E and Sajad MA, 2013. Phytoremediation of heavy metals-concepts and applications. Chemosphere. 91(7): 869-881.

Al-Ubaidy HJ and Rasheed KA, 2015. Phytoremediation of cadmium in river water by Ceratophyllum demersum. World J. Exp. Biosci. 3: 14-17.

Bunluesin S, Kruatrachue M, Pokethitiyook P, Lanza GR, Upatham ES and Soonthornsarathool V, 2004. Plant screening and comparison of Ceratophyllum demersum and Hydrilla verticillata for cadmium accumulation. Bull. Environ. Contam. Toxicol. 73: 591-598.

Cao YN, Ma CX, Chen GC, Zhang JF and Xing BS, 2017. Physiological and biochemical responses of Salix integra Thunb. under copper stress as affected by soil flooding. Environ. Pollut. 225: 644-653.

Cedergreen N, 2008. Is the growth stimulation by low doses of glyphosate sustained over time? Environ. Pollut. 156: 1099-1104.

Chen M, Zhang LL, Li J, He XJ and Cai JC, 2015. Bioaccumulation and tolerance characteristics of a submerged plant (Ceratophyllum demersum L.) exposed to toxic metal lead. Ecotoxicol. Environ. Saf. 122: 313-321.

Das S, Goswami S and Talukdar AD, 2016. Physiological responses of water hyacinth, Eichhornia crassipes (Mart.) Solms, to cadmium and its phytoremediation potential. Turk. J. Biol. 40: 84-94.

Dogan M, Karataş M and Aasim M, 2018. Cadmium and lead bioaccumulation potentials of an aquatic macrophyte Ceratophyllum demersum L.: A laboratory study. Ecotoxicology and Environmental Safety. 148: 431-440.

Doğan M, Karataş $M$ and Aasim M, 2018. In vitro Koşullarda Ceratophyllum demersum L.'un Krom (III) Akümülasyonunun Araştırılması. KSÜ Tarım ve Doğa Derg. 21: 277-285.

Duman F and Koca FD, 2014. Single and combined effects of exposure concentration and duration on biological responses of Ceratophyllum demersum L. exposed to $\mathrm{Cr}$ species. Int. J. Phytoremediat. 16: 1192-1208.

Duman F, Şahan S, Ceylan A and Koca FD, 2010. Biological Responses of Ceratophyllum demersum L. Exposed to Chromium ( $\mathrm{Cr}+6)$. SDU J. Sci. 5: 163-171.

Fu F and Wang Q, 2011. Removal of heavy metal ions from wastewaters: A review. J. Environ. Manage.
92: 407-418.

George E, Hal M and Klerk G, 2008. Micropropagation: Uses and Methods. Plant Propagation by Tissue Culture. Springer, Netherlands, pp. 30.

Harguinteguy CA, Noelia Cofré M, Fernández-Cirelli A and Luisa Pignata M, 2016. The macrophytes Potamogeton pusillus L. and Myriophyllum aquaticum (Vell.) Verdc. as potential bioindicators of a river contaminated by heavy metals. Microchem. J. 124: 228-234.

Hassan NA and Al-Khalidi SHH, 2018. Phytoremediation of lead by Ceratophyllum demersum - Lab Work. Int. J. Curr. Microbiol. Appl. Sci. 7(5): 2002-2008.

Kara Y and Zeytunluoglu A, 2007. Bioaccumulation of toxic metals $(\mathrm{Cd}$ and $\mathrm{Cu}$ ) by Groenlandia densa (L.) Fourr. Bull. Environ. Contam. Toxicol. 79: 609-612.

Karataş M, Aasim M and Doğan M, 2014. Multiple shoot regeneration of Ceratophyllum demersum L. on agar solidified and liquid mediums. Fres. Environ. Bull. 23: 3-9.

Mishra S, Srivastava S, Tripathi RD, Kumar R, Seth CS and Gupta DK, 2006. Lead detoxification by coontail (Ceratophyllum demersum L.) involves induction of phytochelatins and antioxidant system in response to its accumulation. Chemosphere. 65: 1027-1039.

Murashige T and Skoog F, 1962. A revised medium for rapid growth and bioassays with tobacco tissue cultures. Physiol. Plant. 15: 473-497.

Polechonska L, Klink A, Dambiec M and Rudecki A, 2018. Evaluation of Ceratophyllum demersum as the accumulative bioindicator for trace metals. Ecol. Indic. 93: 274-281.

Sadik R, Lahkale R, Hssaine N, ElHatimi W, Diouri $M$ and Sabbar E, 2015. Sulfate removal from wastewater by mixed oxide-LDH: equilibrium, kinetic and thermodynamic studies. J. Mater. Environ. Sci. 6: 2895-2905.

Sasmaz M, Obek E and Sasmaz A, 2016. Bioaccumulation of uranium and thorium by Lemna minor and Lemna gibba in $\mathrm{Pb}-\mathrm{Zn}-\mathrm{Ag}$ tailing water. Bull. Environ. Contam. Toxicol. 97(6):832-837.

Singh R, Tripathi RD, Dwivedi S, Kumar A, Trivedi PK and Chakrabarty D, 2010. Lead bioaccumulation potential of an aquatic macrophyte Najas indica are related to antioxidant system. Bioresour. Technol. 101(9): 
3025-3032.

Snedecor GW and Cochran WG, 1997. Statistical Methods. The Iowa State University Press, Iowa. USA.

Terzi H and Yildiz M, 2011. Heavy metals and phytoremediation: physiological and molecular mechanisms. AKU-J. Sci. Eng.11: 1-22.

Thiébaut G, 2012. Macrophytes as indicators of the quality and ecological status of waterbodies and for use in removing nutrients and metals. In: Aquatic Ecosystem Research Trends, New York, USA. pp. 10-14.

VahdatiRaad L and Khara H, 2012. Heavy metals phytoremediation by aquatic plants (Hyrocotyle ranocloides, Ceratophyllum demersum) of Anzali lagoon. IJMASE. 2(4): 249-254.

Wang Z, Yao L, Liu G and Liu W, 2014. Heavy metals in water, sediments and submerged macrophytes in ponds around the Dianchi Lake. China. Ecotox. Environ. Saf. 107: 200-206

Xu X, Yang B, Qin G, Wang H, Zhu Y, Zhang K and Yang H, 2019. Growth, accumulation, and antioxidative responses of two Salix genotypes exposed to cadmium and lead in hydroponic culture. Environ. Sci. Pollut. Res. Int. 26: 1977019784.
Zayed A, Gowthaman S and Terry N, 1998. Phytoaccumulation of trace elements by wetland plants: I. Duckweed. J. Environ. Qual. 27: 715721.

Zheng X, Xu X, Yekeen TA, Zhang Y, Chen A, Kim SS, Dietrich KN, Ho, SM, Lee SA, Reponen T and Huo X, 2016. Ambient air heavy metals in PM 2.5 and potential human health risk assessment in an informal electronic-waste recycling site of China. Aerosol Air Qual. Res. 16: 388-397.

\section{Contribution of Authors}

Aasim M: Conceived idea, designed research methodology, statistical analysis and manuscript writing

Aydın S: Conceived idea, designed research methodology, data analysis, manuscript final reading and approval

Karataş M: Conceived idea, literature review and manuscript final reading and approval

Aydın ME: Literature review, data analysis and data interpretation

Soğukpinar C: Designed research methodology, data collection and data analysis

Sevinc C: Literature review, data analysis and manuscript final reading 